\title{
Assessment of Grain Storage Structures and Containers in Relation to Build-Up of Insect and Rodent Pests in Southwestern Ethiopia
}

\author{
Nezif Abamecha Wakuma Bayissa Kumela Dibaba \\ Jimma University College of Agriculture and Veterinary Medicine, P. O. Box 307, Jimma, Ethiopia
}

\begin{abstract}
This study was designed to assess farmers grain storage containers in relation to buildup of storage pests in three selected districts of southwestern Ethiopia. One district was selected from each zone based on the production potential of selected grain crops such as maize, sorghum, wheat and faba bean. Then, 25 households were randomly selected from each district to collect stored grain samples used for the identification of storage insect pests, and grain samples were taken from different storage structures, including un-plastered and plastered gombisa, gumbi, and polypropylene sacks. The results showed that the dominant insect species in maize, sorghum and wheat grains were weevils (Sitophilus spp.) followed by the Angoumois grain moth (Sitotroga cerealella Olivier) and flour beetles (Tribolium spp.), while the bean weevil (Zabrotes spp.) was the only species recovered from stored faba beans. High numbers of insects were recorded from both plastered and un-plastered gombisa, gumbi and polypropylene sacks. In addition, the number of each insect pest in each storage method recorded per $100 \mathrm{~g} \mathrm{~g}^{-1}$ grain increased as the duration of grain storage increased. The results of this study also demonstrated that most of the farmers in the study areas perceived insect pests and rodents as the main postharvest pests causing considerable losses of stored grains. The poor storage systems of farmers predispose the stored grains to insect and rodent attacks. Thus, there is a need to train farmers on storage hygiene and to develop and disseminate efficient grain storage facilities to reduce losses in grain stores. Moreover, further studies need an improved pest detection method, such as the use of bioacoustics tools, to manage pests associated with grain stores.
\end{abstract}

Keywords: grain, insects, rodents, storage

DOI: $10.7176 /$ FSQM/93-04

Publication date: January $31^{\text {st }} 2020$

\section{Introduction}

Cereal crops, such as maize, sorghum and wheat, are the main food staples and sources of income for millions of smallholder farmers in Ethiopia. However, poor storage systems make grains vulnerable to attacks from insect and rodent pests, which lead to a considerable amount of losses. Subsequently, smallholder farmers are unable to keep the grain in storage for long and are hence forced to sell their grain soon after harvest (Tefera and Adebayo, 2012). According to the FAO (2010), an approximately $20-30 \%$ loss of grains occurred globally, with an estimated monetary value of more than US\$4 billion annually. Recently, Kumar and Kalita (2017) reported approximately $50-60 \%$ losses of cereal grains during storage due to technical inefficiency. In Ethiopia, the average grain losses due to storage insect pests are estimated to be 10-30\% (Tadesse, 2005; MoARD, 2010). Among many storage insect pests, grain weevils, Sitophilus spp. (Coleoptera: Curculionidae), and the Angoumois grain moth, Sitotroga cerealella (Olivier) (Lepidoptera: Gelechiidae), are major pests of cereal crops in Ethiopia (Demisse et al., 2008; Tefera, 2011). Bean bruchids (Coleoptera: Bruchidae), such as Zabrotes subfasciatus and Acanthoscelides obtectus, are the main pests of legume crops, such as faba bean, and cause heavy losses in terms of both quality and quantity of stored legumes (Abate et al., 2000).

Farmers in Ethiopia, similar to those in other African countries, use traditional storage facilities made from locally available materials. Such storage structures often fail to protect the stored grains from insect pests and damage by rodents. Traditional storage structures provide ideal conditions for the multiplication of storage insect pests and rodents. Although most smallholder farmers keep grain for a relatively shorter period, substantial losses occur to stored grains.

Rodents are also a major postharvest pest, causing a significant amount of losses and contamination of stored grains during storage (Gregory, 2002; Ognakossan et al., 2016). To design effective postharvest pest management methods, knowledge of major pests and their relative abundances in relation to storage facilities is essential. However, little information is available about storage insect pest infestations in relation to storage facilities. Furthermore, there is no empirical information about farmers' perceptions of rodent pests in southwestern Ethiopia. Therefore, the aim of the present study was to assess the main storage insect pests and their relative abundance in traditional storage types in three districts in southwestern Ethiopia. A further objective was to assess farmers' perceptions of stored grain losses due to insect and rodent pests. 


\section{Material and methods}

\subsection{Study site description}

Study samples were collected from the major target grain growing areas of Jimma, West Shoa and East Wollega zones, Oromia Regional State, Ethiopia. One district was purposively selected from each zone on the bases of target grain production status and the expectation that the areas are generally favourable for storage pest infestations owing to their environmental conditions. Accordingly, Omo Neda from Jimma, Bako Tibe from West Shoa and Gudeya Bila from East Wollega Zones zones were selected for experimental sample collection.

\subsection{Sampling procedure and sample collection}

This study concentrated on the four major grain crops, including maize, sorghum, wheat and faba bean. According to the production status obtained from the agricultural office, maize and sorghum have high production status in the Jimma and West Shoa zones, whereas wheat and faba bean are high in the East Wollega zone. A total of 240 farmers' stores from all districts were visited and samples collected. The samples were obtained from five local storage facilities, including gombisa, gotera, gumbi, and sacks. The selection of farmers and samples was made at random in such a way that they are the representative of the district. When a selected storage area did not have a target grain, the next storage area was taken as a substitute.

A total of $600 \mathrm{~g}$ of target grain samples from the top $(200 \mathrm{~g})$, middle $(200 \mathrm{~g})$ and bottom $(200 \mathrm{~g}) \mathrm{of}$ each storage structure were collected. The grain samples taken from the top, middle and bottom of a storage structure were then bulked together to create a composite sample. Subsequent samples were collected from the same stores every month for up to five months, from March to July 2017. For storage insect pest studies, grain samples collected at monthly intervals were used. The first sample collection was conducted after the target grain was stored for one month. Grain samples were enclosed in plastic bags and brought to the Postharvest Management Laboratory of Jimma University, College of Agriculture and Veterinary Medicine (JUCAVM) for laboratory analysis.

\subsection{Storage insect identification}

Each grain sample taken from the study was brought to the laboratory at Jimma College of Agriculture and sieved through a 2-mm mesh as previously described by Abraham et al. (1995) and Abraham (1996) for the identification of insect pests. Both live and dead insects removed from each sample were counted, placed individually in a veil containing a 70\% ethanol solution and identified using the procedures described by Borror et al. (2005) and Gibb and Oseto (2005). The collected insects from all grains and different storage structures were identified through their morphological characteristics using a dissecting microscope (at magnification x25-60) for species identification.

\subsection{Questionnaire}

The questionnaire was designed to collect information about farmers' knowledge and perceptions of losses due to insects and rodents in different types of storage structures, including gombisa, both plastered and unplastered, polypropylene sacks, and gumbi. The naming of traditional storage structures varies from place to place. Gotera is similar to gombisa, except that the wall is plastered with mud or cow dung and teff straw in the case of Gotera, which is a common storage structure in Bako Tibe and Gudeya Bila, and gombisa is common in the Jimma zone.

\subsection{Statistical Analysis}

A $3 \times 2$ factorial design was used for the determination of damaged grain, weight loss, and the nutritional composition of maize and sorghum kernels stored in the farmers' traditional storage structures using two storage types (gombisa and polypropylene bag) and three storage duration levels ( $1^{\text {st }}, 3$, and 5 months). Data on the insect count was analysed using a one-way analysis of variance (ANOVA) using a generalized linear model. The insect count data were square-root transformed to normalize the variances. The significance level was set at 0.05 , and means were separated by Tukey's Honestly Significant Difference test.

\section{Result}

\subsection{Insect species composition and abundance}

The insect species recorded in stored maize grain both in Omo Nada and Bako Tibe were weevils (Sitophilus spp.), Angoumois grain moth (Sitotroga cerealella), and flour beetle (Tribolium spp.). There were significant differences in the number of insect species recorded during storage periods $(\mathrm{P}<0.05)$, but the storage type did not affect the number of insects (Tables 1 and 2). The same species of insect pests were recorded from stored sorghum and wheat grains in both districts, but the number of Sitophilus spp. were relatively lower compared to that in maize (Tables 3,4 and 5). The number of each storage insect pest recorded per $100 \mathrm{~g}^{-1}$ grain increased as the duration of grain storage increased.

Mexican bean weevil (Zabrotes subfasciatus) was the only insect pest recorded from faba bean stored in the 
three traditional storage structures (Table 6). The number of Z. subfasciatus varied significantly in the different storage types $(\mathrm{P}=0.045)$ and storage duration $(\mathrm{P}=0.000)$. The number of $Z$. subfasciatus recorded per $100 \mathrm{~g}^{-1}$ grain increased as the duration of grain storage increased.

\subsection{Farmers' perceptions of storage losses due to insect and rodent pests}

The magnitudes of perceived storage losses due to insect pests are presented in Table 7. In all the study districts, the majority of the farmers, ranging from 39.2 to $72 \%$, perceived losses of $51-75 \%$ of grains stored in gombisa. On the other hand, most of the farmers perceived $26-50 \%$ damage of grains stored in polypropylene sacks. Similarly, the majority of farmers reported estimated losses of $26-50 \%$ of grains stored in gumbi. Only a small proportion of farmers reported estimated losses of over $75 \%$.

The majority of farmers, with the exception of the Gudeya Bila district, estimated approximately $26-50 \%$ damage of grains stored in gombisa due to rodents (Table 8). Most of the farmers (28\% to 56.7\%) estimated 26$50 \%$ losses of grains stored in polypropylene bags. On the other hand, the majority of farmers in the Omo Nada and Bako Tibe districts estimated 26-50\% and 51-75\% losses of grains stored in gumbi, respectively (Table 8)

\section{Discussion}

In the present study, Sitophilus spp., S. cerealella, and Tribolium spp. were recorded in maize, sorghum and wheat grains stored in traditional storage structures (gombisa and gumbi) and polypropylene bags. In stored faba bean, Z. subfasciatus was recorded as the main storage pest. These species are reported as the main storage insect pests of cereal grains in different parts of Ethiopia (e.g., Mendesil et al. (2007; Demissie et al., 2008; Tadesse et al., 2008; Tefera, 2016) and other African countries (e.g., Midega et al., 2016; Abass et al., 2018). In all the study districts and storage types, Sitophilus spp. were the most abundant species, which is corroborated by the findings of various studies, such as Mlambo et al. (2017). Sitotroga cerealella was also widely distributed and the dominant species attacking different cereal crops in Africa (Hill, 2002; Mlambo et al., 2017). According to Golob (2009), $S$. cerealella is mainly associated with unshelled maize, wheat and sorghum soon after harvest.

Cereal growers in study areas are common in other parts of the country and are predominantly smallholder farmers who keep grains for shorter durations, mainly for home consumption or to sell in a local market. However, during this storage period, stored grain is vulnerable to damage by insect pests. As a result, farmers are forced to sell their produce at very low prices immediately after harvest. As demonstrated in this study, the number of each storage insect pest recorded increased as the duration of grain storage increased, resulting in considerable losses. Tefera et al. (2011) observed an increase in grain damage and weight loss due to an increase in densities of storage insects and the duration of the storage period. The fact that severe losses occurred in storage due to insect pests is mainly attributed to poor storage systems (Tefera, 2011). In Ethiopia, similar to most sub-Saharan African countries, grain storage systems are of traditional types, which are poorly constructed from locally available materials that cannot protect stored grains from abiotic and biotic agents, such as insect pests and fungal diseases. Furthermore, poor storage systems enhance storage insect pests (Ng'ang'an et al., 2016). For example, in Ethiopia, poor postharvest management causes $20-30 \%$ loss of grains (Tefera, 2016). Consequently, there is a significant amount of postharvest losses in smallholder settings in the country (e.g., Tadesse et al., 2008; Tefera, 2016; Garbaba et al., 2017). During the focused group discussions, farmers highlighted losses incurred during storage that agreed with these results.

Although the estimation of the proportion of grains damaged by storage insect pests varied across districts and storage types, the majority of farmers estimated losses ranging from 26 to $50 \%$. A survey done in Ethiopia showed that insect pests were considered by a majority of the farmers $(60.13 \%)$ as a severe problem in storage (Beyene and Ayelew, 2015). In Kenya, Midega et al. (2016) reported losses of 26-75\%, which was mentioned by the majority of respondents, and the authors stated that the proportion of grains damaged varied from place to place. A survey conducted in Cote D'ivoire by Niamketchi et al. (2016) reported approximately 36.8\% losses of stored maize by insect pests. According to Fripong (2016), 61.5\% of the respondents indicated that pest infestations were the major challenge encountered during the storage of maize grains in Ghana.

Rodents are one of the major postharvest pests causing a considerable amount of losses. In this study, most farmers considered rodents a serious problem that causes estimated grain losses of $26-50 \%$. A study conducted in Kenya showed that farmers perceived rodents causing up to $43 \%$ and $30 \%$ of losses of maize stored on cobs and shelled grain, respectively (Ognakossan et al., 2016).

\section{Conclusion}

Farmers in all the surveyed districts perceived that insect and rodent pests were the major challenge that caused high damages and losses to stored maize, sorghum, wheat, and faba bean. Generally, farmers' opinions on the extent of losses of stored grains varied with grain type, district and the type of structure used. On the other hand, the high grain losses estimated in the survey districts showed that pest management practices of farmers are inadequate to reduce losses to insect pests and rodent attacks. The laboratory study on insect populations associated 
with stored grains revealed that storage duration and the structures used influences the abundance of insect species in all the study districts. Regardless of grain storage duration and the structures used, weevils (Sitophilus spp.) were found to be the dominant species in stored maize, sorghum and wheat in all the study districts. However, bean bruchid, Z. subfasciatus, was the only insect species that attacked stored faba beans. Improved storage systems that provide adequate protection for stored grains from pest damage and at the same time maintain grain quality over long periods need to be promoted in the study areas.

\section{Acknowledgements}

The International Centre of Insect Physiology and Ecology (ICIPE) RELOAD project is acknowledged for financial support during this study.

We also gratefully acknowledge the financial support by the UK's Department for International Development (DFID); the Swedish International Development Cooperation Agency (Sida); the Swiss Agency for Development and Cooperation (SDC); and the Kenyan Government. The views expressed herein do not necessarily reflect the official opinions of the donors.

\section{References}

Abate, T., van Huis, A., Ampofo, J.K.O., 2000. Pest management in traditional agriculture: an African perspective. Annual Review of Entomology 45, 631-659.

Abraham, T., (1996), Insects and other arthropods recorded from stored maize in western Ethiopia. African Crop Science Journal, 4(3), pp.339-343.

Abraham, T., 1997. Arthropods associated with stored maize and farmers' management practices in the Bako area, western Ethiopia. PMJE 1 (1-2). Addis Ababa, Ethiopia.

Abraham, T., Amare, A., Emana, G., and Tadele, T., 2008. Review of research on post harvest pests. In: Increasing Crop Production through Improved Plant Protection-Volume I.

Abraham, T., Tadesse. G., and Mengistu, H., 1995. Comparison of some maize genotypes for resistance to the maize weevil, Sitophilus zeamais Motsch. (Coleoptera: Curculionidae) in Ethiopia. In: Proceedings of the Fourth Eastern and Southern Africa Regional Maize Conference. (D.C. Jewell, S.R. Waddington, J.K. Ransom and P.V. Pixley eds.) held in Harare, Zimbabwe, 28 March- 1 April 1994.

Baidoo1, P., Mochiah, M., and Akyaw, M., 2010. Levels of infestation on three different portions of the maize cob by the weevil Sitophilus zeamais (Motschulsky). Journal of Science and Technology, 30(3): 21-26.

Beyene, Y., and Ayelew. D., 2015. Report On Postharvest Loss Assessment Survey-in Ethiopia. Baseline Information on Maize (Zea mays L.) Postharvest Loss Assessment.

Borror, D., De long, D., Triplehorn, C., and Norman, F.J., 2005. Introduction to the study of insects. Peter marshal puplisher, USA., pp; 377-610.

Boxall, R., 2002. Damage and loss caused by the larger grain borer Prostephanus truncatus. Integrated Pest Management Review 7: 105-121.

Demissie, G., Tefera, T., and Abraham, T., 2008. Importance of husk covering on field infestation of maize by Sitophilus zeamais Motsch. (Coleoptera: Curculiodea) at Bako, western Ethiopia. African Journal of Biology, 7: 3774-3779.

Emana, G., Ahmed, I., Fridissa, I., 2003. Review of lowland pulse insect pest research in Ethiopia. Proceedings of grain legume workshop, 22-27 September, 2003, Addis Ababa, Ethiopia.

Fripong. E., 2016. Effects of commonly used storage methods, chemical treatment and storage period on maize grains quality in ejura-sekyedumasi municipality in the ashanti region.MPHIL. Thesis Kwame Nkrumah University of Science and Technology.

Gibb, T., and Oseto, C., 2005. Arthropod Collection and Identification: Laboratory and Field Techniques.

Gregory, K., 2002 Information on common pests [Internet]. Available from:http://www.statistics of common pests.htm/ (cited 16 March 2002).

Haile-Gabriel, A., and Hundie, B., 2006, Farmers' Post-Harvest Grain Management Choices under Liquidity Constraints and Impending Risks: Implications for Achieving Food Security Objectives in Ethiopia. Poster paper prepared for presentation at the International Association of Agricultural Economists Conference, Gold Coast, Australia, and August 12-18.

Kilonzo, B., 2005. Rodent pests and their management in Tanzania. Compendium 1.Mzumbe Book Project, Morogoro.

Mendesil, E., Abdeta, C., Tesfaye, A., Shumeta, Z., and Jifar, H., 2007. Farmers' perceptions and management practices of insect pests on stored sorghum in southwestern Ethiopia. Crop Protection, 26(12).

Midega. C., Murage A., Pittchar, J., and Khan, Z., 2016. Managing storage pests of maize: Farmers' knowledge, perceptions and practices in western Kenya.Crop Protection Journal. Homepage: www.elsevier.com/locate/cropro.

Nukenine, E., 2010. Stored product protection in Africa: Past, present and future. 10th International Working 
Conference on Stored Product Protection.DOI: 10.5073/jka.2010.425.177.

Niamketchi Léonce, Biego Godi Henri, Sidibe Daouda, Coulibaly Adama, Konan NeeguessanYsidor, Chatigre Olivier (2016), Changes in Aflatoxins Contents of the Maize (Zea Mays L.) Stored in Clay Granaries with use of Biopesticides from Rural Conditions and Estimation of their Intake", International Journal of Environmental \& Agriculture Research, II (5)

Odogola, W., 1994. Postharvest management and storage of food legumes. Technical Systems for Agriculture. agrotec undp/ops, Harare, Zimbabwe.

Rees, D., 2004. Insects of stored products. CSIRO Publishing. Melbourne, Victoria.

Sori, W., 2014. Storage pests of maize and their status in Jimma Zone, Ethiopia. African Journal of Agricultural Research, 7(28): 4056-4060.

Sori, W., and Ayana, A., 2012. Storage pests of maize and their status in Jimma Zone, Ethiopia. African Journal of Agricultural Research, 7(28), pp.4056-4060.

Sori, W., Befikadu, D., Bultosa, G., and Sethu, M.R., 2012. Influence of agro ecology, traditional storage containers and major insect pests on stored maize (Zea mays L.) in selected woredas of Jimma zone. Asian journal of plant science 11(5)-226-234.

Tapondjou, A., Bouda, H., Fontem, D., Zapfack, L., Lontsi, D., Sondengam, BL., 2000. Local plants used for traditional stored product protection in the Menoua division of the Western Highlands of Cameroon, IOBC Bulletin, pp. 73-77.

Tadele, T., Mugo, S., and Likhayo, P., 2011. Effect of insect population density and storage time on grain damage and weight loss in maize due to the maize weevil, Sitophilus zeamais and the larger grain borer, Prostephanus truncates. African Journal of Agricultural Research, 6: 2249-2254.

Tadele, T., and Adebayo, A., 2012. Improved postharvest technologies for promoting food storage, processing, and household nutrition in Tanzania. PP.1-20. International Institute of Tropical Agriculture.

Zonal office of finance and economic development office (ZOFEDO). 2017. Physical And Socio Economic Profile Of Jimma, West Shoa And East Wollega Zones South Western Ethiopia, Unpublished Report.

Table 1. Number of insect pests sampled from maize grain $\left(100 \mathrm{~g}^{-1}\right.$ grain $)$ in the Omo Nada district, southwestern Ethiopia.

\begin{tabular}{|l|l|l|l|l|l|l|}
\hline $\begin{array}{l}\text { Storage } \\
\text { periods }\end{array}$ & \multicolumn{2}{|l|}{ Gombisa/Unplastered } & \multicolumn{2}{l|}{ Polypropylene bag } \\
\hline & $\begin{array}{l}\text { Sitophilus } \\
\text { spp. }\end{array}$ & Tribolium spp. & $\begin{array}{l}\text { Sitotroga } \\
\text { cerealella }\end{array}$ & $\begin{array}{l}\text { Sitophilus } \\
\text { spp. }\end{array}$ & $\begin{array}{l}\text { Tribolium } \\
\text { spp. }\end{array}$ & $\begin{array}{l}\text { Sitotroga } \\
\text { cerealella }\end{array}$ \\
\hline $1^{\text {st }}$ round & $6.0 \pm 1.53 \mathrm{a}$ & $2.0 \pm 1.53 \mathrm{a}$ & $2.0 \pm 1.20 \mathrm{ab}$ & $5.7 \pm 1.85 \mathrm{a}$ & $0.7 \pm 0.33 \mathrm{~b}$ & $4.7 \pm 0.33$ \\
\hline $3^{\text {rd }}$ round & $31.3 \pm 2.68 \mathrm{~b}$ & $3.3 \pm 0.88 \mathrm{~b}$ & $3.3 \pm 1.76 \mathrm{ab}$ & $8.0 \pm 1.73 \mathrm{a}$ & $2.0 \pm 0.00 \mathrm{ab}$ & $7.7 \pm 2.18$ \\
\hline $5^{\text {th }}$ round & $36.3 \pm 2.64 \mathrm{c}$ & $6.0 \pm 1.52 \mathrm{c}$ & $6.0 \pm 2.31 \mathrm{a}$ & $16.0 \pm 1.73 \mathrm{~b}$ & $4.0 \pm 1.00 \mathrm{ab}$ & $7.3 \pm 1.53$ \\
\hline
\end{tabular}

Means within a column followed by different letters are significantly different at $\mathrm{P}<0.05$ (Tukey test)

Table 2. Number of insect pests sampled from maize grain $\left(100 \mathrm{~g}^{-1}\right.$ grain $)$ in the Bako Tibe district, southwestern Ethiopia

\begin{tabular}{|l|l|l|l|l|l|l|}
\hline \multirow{2}{*}{$\begin{array}{l}\text { Storage } \\
\text { periods }\end{array}$} & \multicolumn{4}{|l|}{ Gombisa /Plastered } & \multicolumn{2}{l|}{ Polypropylene bag } \\
\cline { 2 - 7 } & $\begin{array}{l}\text { Sitophilus } \\
\text { spp. }\end{array}$ & $\begin{array}{l}\text { Tribolium } \\
\text { spp. }\end{array}$ & $\begin{array}{l}\text { Sitotroga } \\
\text { cerealella }\end{array}$ & $\begin{array}{l}\text { Sitophilus } \\
\text { spp. }\end{array}$ & $\begin{array}{l}\text { Tribolium } \\
\text { spp. }\end{array}$ & $\begin{array}{l}\text { Sitotroga } \\
\text { cerealella }\end{array}$ \\
\hline $1^{\text {st }}$ round & $2.7 \pm 2.18 \mathrm{~b}$ & $0.3 \pm 0.33 \mathrm{a}$ & $0.7 \pm 0.33 \mathrm{a}$ & $2.7 \pm 1.45 \mathrm{a}$ & $0.7 \pm 0.67 \mathrm{a}$ & $1.3 \pm 0.33 \mathrm{bc}$ \\
\hline $3^{\text {rd }}$ round & $17.7 \pm 2.17 \mathrm{~b}$ & $1.0 \pm 0.58 \mathrm{ab}$ & $6.3 \pm 2.40 \mathrm{~b}$ & $12.0 \pm 1.53 \mathrm{~b}$ & $1.3 \pm 1.33 \mathrm{a}$ & $4.0 \pm 2.65 \mathrm{abc}$ \\
\hline $5^{\text {th }}$ round & $44.3 \pm 3.81 \mathrm{a}$ & $1.3 \pm 0.67 \mathrm{ab}$ & $11.3 \pm 2.60 \mathrm{~b}$ & $15.0 \pm 3.00 \mathrm{~b}$ & $4.3 \pm 1.45 \mathrm{~b}$ & $9.3 \pm 0.33 \mathrm{ab}$ \\
\hline
\end{tabular}

Means within a column followed by different letters are significantly different at $\mathrm{P}<0.05$ (Tukey test)

Table 3. Number of insect pests sampled from sorghum grain (100 $\mathrm{g}^{-1}$ grain $)$ in the Omo Nada district, southwestern Ethiopia

\begin{tabular}{|c|c|c|c|c|c|c|}
\hline \multirow[b]{2}{*}{$\begin{array}{l}\text { Storage } \\
\text { periods }\end{array}$} & \multicolumn{3}{|c|}{ Gombisa /Unplastered } & \multicolumn{3}{|c|}{ Polypropylene bag } \\
\hline & $\begin{array}{l}\text { Sitophilus } \\
\text { spp. }\end{array}$ & $\begin{array}{l}\text { Tribolium } \\
\text { spp. }\end{array}$ & $\begin{array}{l}\text { Sitotroga } \\
\text { cerealella }\end{array}$ & Sitophilus spp. & $\begin{array}{l}\text { Tribolium } \\
\text { spp. }\end{array}$ & $\begin{array}{l}\text { Sitotroga } \\
\text { cerealella }\end{array}$ \\
\hline $1^{\text {st }}$ round & $8.7 \pm 2.18$ & $0.3 \pm 0.33$ & $0.7 \pm 0.67$ & $2.0 \pm 1.15$ & $0.0 \pm 0.00$ & $2.3 \pm 0.88$ \\
\hline $3^{\text {rd }}$ round & $9.3 \pm 1.20$ & $1.0 \pm 0.88$ & $3.7 \pm 1.86$ & $8.3 \pm 2.53$ & $1.3 \pm 0.67$ & $1.7 \pm 0.88$ \\
\hline $5^{\text {th }}$ round & $22.7 \pm 4.37$ & $5.3 \pm 2.85$ & $8.3 \pm 1.67$ & $20.3 \pm 3.22$ & $7.3 \pm 0.84$ & $7.0 \pm 4.73$ \\
\hline
\end{tabular}

Means within a column followed by different letters are significantly different at $\mathrm{P}<0.05$ (Tukey test) 
Table 4. Number of insect pests sampled from sorghum (100 g-1 grain) in the Bako Tibe district, southwestern Ethiopia

\begin{tabular}{|l|l|l|l|l|l|l|}
\hline \multirow{2}{*}{$\begin{array}{l}\text { Storage } \\
\text { periods }\end{array}$} & \multicolumn{4}{|l|}{ Gombisa /Plastered } & \multicolumn{2}{l|}{ Polypropylene bag } \\
\cline { 2 - 7 } & Sitophilus spp. & $\begin{array}{l}\text { Tribolium } \\
\text { spp. }\end{array}$ & $\begin{array}{l}\text { Sitotroga } \\
\text { cerealella }\end{array}$ & Sitophilus spp. & $\begin{array}{l}\text { Tribolium } \\
\text { spp. }\end{array}$ & $\begin{array}{l}\text { Sitotroga } \\
\text { cerealella }\end{array}$ \\
\hline $1^{\text {st }}$ round & $5.3 \pm 0.67 \mathrm{bc}$ & $0.3 \pm 0.33 \mathrm{a}$ & $0.3 \pm 0.33 \mathrm{c}$ & $1.7 \pm 0.88 \mathrm{c}$ & $0.0 \pm 0.00$ & $1.7 \pm 0.67 \mathrm{c}$ \\
\hline $3^{\text {rd }}$ round & $19.3 \pm 3.22 \mathrm{ab}$ & $1.0 \pm 0.58 \mathrm{ab}$ & $3.0 \pm 1.53 \mathrm{bc}$ & $9.7 \pm 0.88 \mathrm{abc}$ & $1.3 \pm 0.88$ & $2.0 \pm 1.15 \mathrm{c}$ \\
\hline $5^{\text {th }}$ round & $25.0 \pm 4.00 \mathrm{a}$ & $2.7 \pm 1.33 \mathrm{~b}$ & $7.3 \pm 0.88 \mathrm{ab}$ & $21.3 \pm 2.41 \mathrm{ab}$ & $3.7 \pm 1.20$ & $7.7 \pm 0.88 \mathrm{a}$ \\
\hline
\end{tabular}

Means within a column followed by different letters are significantly different at $\mathrm{P}<0.05$

(Tukey test)

Table 5. Number of insect pests sampled from wheat (100 g-1 grain) in the Gudeya Bila district, southwestern Ethiopia

\begin{tabular}{|l|l|l|l|l|l|l|}
\hline \multirow{2}{*}{$\begin{array}{l}\text { Storage } \\
\text { periods }\end{array}$} & \multicolumn{2}{|l|}{ Gombisa/ Plastered } & \multicolumn{2}{l|}{ Polypropylene bag } & Gumbi \\
\cline { 2 - 7 } & $\begin{array}{l}\text { Sitophilus } \\
\text { spp. }\end{array}$ & $\begin{array}{l}\text { Sitotroga } \\
\text { cerealella }\end{array}$ & $\begin{array}{l}\text { Sitophilus } \\
\text { spp. }\end{array}$ & $\begin{array}{l}\text { Sitotroga } \\
\text { cerealella }\end{array}$ & $\begin{array}{l}\text { Sitophilus } \\
\text { spp. }\end{array}$ & $\begin{array}{l}\text { Sitotroga } \\
\text { cerealella }\end{array}$ \\
\hline $1^{\text {st }}$ round & $2.0 \pm 0.57$ & $0.7 \pm 0.67$ & $2.3 \pm 0.33$ & $0.7 \pm 0.33$ & $2.3 \pm 1.45$ & $0.7 \pm 0.33$ \\
\hline $3^{\text {rd }}$ round & $6.3 \pm 0.88$ & $3.0 \pm 0.57$ & $6.0 \pm 2.04$ & $1.0 \pm 1.00$ & $7.0 \pm 0.00$ & $1.3 \pm 0.88$ \\
\hline $5^{\text {th }}$ round & $15.7 \pm 3.83$ & $5.7 \pm 0.88$ & $12.3 \pm 1.20$ & $4.0 \pm 2.31$ & $16.0 \pm 2.51$ & $3.7 \pm 1.20$ \\
\hline
\end{tabular}

Means within a column followed by different letters are significantly different at $\mathrm{P}<0.05$

(Tukey test)

Table 6. Number of insect pests sampled from faba bean (100 g-1 grain) in the Gudeya Bila district, southwestern Ethiopia

\begin{tabular}{|l|l|l|l|}
\hline \multirow{2}{*}{ Period of storage } & \multicolumn{3}{|c|}{ Zabrotes subfasciatus } \\
\cline { 2 - 4 } & Gombisa /Plastered & Polypropylene bag & Gumbi \\
\hline $1^{\text {st }}$ round & $0.7 \pm 0.33 \mathrm{~b}$ & $0.0 \pm 0.00 \mathrm{~b}$ & $0.3 \pm 0.33 \mathrm{~b}$ \\
\hline $3^{\text {rd }}$ round & $5.3 \pm 0.67 \mathrm{ab}$ & $0.7 \pm 0.33 \mathrm{~b}$ & $4.7 \pm 1.00 \mathrm{ab}$ \\
\hline $5^{\text {th }}$ round & $10.7 \pm 1.76 \mathrm{a}$ & $5.0 \pm 1.73 \mathrm{ab}$ & $9.7 \pm 3.84 \mathrm{a}$ \\
\hline
\end{tabular}

Means within a column followed by different letters are significantly different at $\mathrm{P}<0.05$

(Tukey test)

Table 7. Farmer's perception of losses of grain by different storage insect pests in different storage structures and containers in southwestern Ethiopia

\begin{tabular}{|c|c|c|c|c|c|c|}
\hline \multirow{3}{*}{$\begin{array}{l}\text { Estimated } \\
\text { proportion of } \\
\text { losses }\end{array}$} & \multicolumn{2}{|l|}{$\begin{array}{l}\text { Omo Nada } \\
\mathrm{N}=175 \\
\end{array}$} & \multicolumn{2}{|c|}{$\begin{array}{l}\text { Bako Tibe } \\
\mathrm{N}=120\end{array}$} & \multicolumn{2}{|c|}{$\begin{array}{l}\text { Gudeya Bila } \\
\mathrm{N}=82\end{array}$} \\
\hline & \multicolumn{6}{|c|}{ Gombisa un-plastered/plastered } \\
\hline & Maize & Sorghum & Maize & Sorghum & Wheat & Faba bean \\
\hline$<25 \%$ & $22(12.6)$ & $7(4.0)$ & $4(3.3)$ & 0 & 0 & 0 \\
\hline $26-50 \%$ & $42(24.0)$ & $33(18.9)$ & $41(34.2)$ & $56(46.7)$ & $13(15.9)$ & $20(24.4)$ \\
\hline $51-75 \%$ & $106(60.6)$ & $120(68.6)$ & $75(62.5)$ & $47(39.2)$ & $51(62.2)$ & $59(72.0)$ \\
\hline$>75 \%$ & $5(2.9)$ & $15(8.6)$ & 0 & $17(14.2)$ & $18(22.0)$ & $3(3.7)$ \\
\hline \multicolumn{7}{|c|}{ Polypropylene bag } \\
\hline$<25 \%$ & 0 & 0 & $35(29.2)$ & $24(20.0)$ & $16(19.5)$ & $16(19.5)$ \\
\hline $26-50 \%$ & $121(69.1)$ & $131(74.9)$ & $42(35.0)$ & $58(48.3)$ & $52(63.4)$ & $34(41.5)$ \\
\hline $51-75 \%$ & $37(21.1)$ & $21(12.0)$ & $37(30.8)$ & $21(17.5)$ & $14(17.1)$ & $18(22.0)$ \\
\hline$>75 \%$ & $17(9.7)$ & $23(13.1)$ & $6(5.0)$ & $17(14.2)$ & 0 & $14(17.1)$ \\
\hline \multicolumn{7}{|c|}{ Gumbi } \\
\hline$<25 \%$ & 0 & 0 & $34(28.3)$ & 0 & $6(7.3)$ & $6(7.3)$ \\
\hline $26-50 \%$ & $103(58.9)$ & $88(50.3)$ & $13(10.8)$ & $38(31.7)$ & $45(54.9)$ & $35(42.7)$ \\
\hline $51-75 \%$ & $54(30.9)$ & $66(37.7)$ & $33(27.5)$ & $47(39.2)$ & $28(34.1)$ & $38(46.3)$ \\
\hline$>75 \%$ & $18(10.3)$ & $21(12.0)$ & $40(33.3)$ & $35(29.2)$ & $3(3.7)$ & $3(3.7)$ \\
\hline
\end{tabular}

(-) represents types of grain storage containers that are not common in the study area 
Table 8. Farmers perception of losses of grain by rodents in different storage structures and containers in southwestern Ethiopia

\begin{tabular}{|c|c|c|c|c|c|c|}
\hline \multirow{3}{*}{$\begin{array}{l}\text { Estimated } \\
\text { proportion } \\
\text { of losses }\end{array}$} & \multicolumn{2}{|l|}{$\begin{array}{l}\text { Omo Nada } \\
\mathrm{N}=175\end{array}$} & \multicolumn{2}{|l|}{$\begin{array}{l}\text { Bako Tibe } \\
\mathrm{N}=120\end{array}$} & \multicolumn{2}{|c|}{$\begin{array}{l}\text { Gudeya Bila } \\
\mathrm{N}=82\end{array}$} \\
\hline & \multicolumn{6}{|c|}{ Gombisa } \\
\hline & Maize & Sorghum & Maize & Sorghum & Wheat & Faba bean \\
\hline$<25 \%$ & $65(37.1)$ & $60(34.3)$ & $37(30.8)$ & $23(19.2)$ & $3(3.7)$ & $11(13.4)$ \\
\hline $26-50 \%$ & $109(62.3)$ & $93(53.1)$ & $67(55.8)$ & $75(62.5)$ & $7(8.5)$ & $16(19.5)$ \\
\hline $51-75 \%$ & $1(0.6)$ & $22(12.6)$ & $6(5.0)$ & $14(11.7)$ & $72(87.8)$ & $55(67.1)$ \\
\hline$>75 \%$ & 0 & 0 & $10(8.3)$ & $8(6.7)$ & 0 & 0 \\
\hline \multicolumn{7}{|c|}{ Polypropylene bag } \\
\hline$<25 \%$ & $76(43.4)$ & $51(29.1)$ & $21(17.5)$ & $40(33.3)$ & $16(19.5)$ & $26(31.7)$ \\
\hline $26-50 \%$ & $96(54.9)$ & $95(54.3)$ & $68(56.7)$ & $30(25.0)$ & $49(59.8)$ & $23(28.0)$ \\
\hline $51-75 \%$ & $3(1.7)$ & $29(16.6)$ & $31(25.8)$ & $16(13.3)$ & $17(20.7)$ & $23(28.0)$ \\
\hline$>75 \%$ & 0 & 0 & 0 & $34(28.3)$ & 0 & $10(12.2)$ \\
\hline \multicolumn{7}{|c|}{ Gumbi } \\
\hline$<25 \%$ & $2(1.1)$ & $4(2.3)$ & $9(7.5)$ & $7(5.8)$ & $42(51.2)$ & $39(47.6)$ \\
\hline $26-50 \%$ & $107(61.1)$ & $106(60.6)$ & $24(20.0)$ & $19(15.8)$ & $3(3.7)$ & $19(23.2)$ \\
\hline $51-75 \%$ & $19(10.9)$ & $12(6.9)$ & $67(55.8)$ & $55(45.8)$ & $5(6.1)$ & $13(15.9)$ \\
\hline$>75 \%$ & $47(26.9)$ & $53(30.3)$ & $20(16.7)$ & $39(32.5)$ & $32(39.0)$ & $11(13.4)$ \\
\hline
\end{tabular}

(-) represents types of grain storage containers that are not common in the study area 